АДМІНІСТРАТИВНІ ПРОЦЕДУРИ В ПУБЛІЧНІЙ СЛУЖБІ УКРАЇНИ: ЗАГАЛЬНА ХАРАКТЕРИСТИКА РОБОТИ

\title{
ADMINISTRATIVE PROCEDURES IN THE PUBLIC SERVICE OF UKRAINE: GENERAL CHARACTERISTICS OF THE WORK
}

У статті здійснено комплексне дослідження адміністративних процедур на публічній службі в Україні, розглядаються види адміністративних прочедур і порядок їх проходження. Увага приділяється суті публічної служби, їі структурних елементів, а також поняття адміністративної процедури і ї правовій природі. Розглядаються нормативно-правові акти, які регулюють правові основи проведення адміністративних процедур. Зроблено висновки про необхідність ухвалення єдиного нормативного акта, який би регулював порядок проходження службовцями публічної служби з усіма властивими їи процедурами. У статті міститься характеристика класифрікації адміністративних процедур, характерна для публічної служби. Аналізуютьсяорганізаційніпроцедури напублічній службі, які складаються із процедур вступу до неї, процедур просування по службі, процедур оцінювання діяльності публічних службовців, заохочувальних адміністративних прочедур для публічних службовиів, і юрисдикційні адміністративні процедури на публічній службі, які складаються з адміністративних процедур загального та спеціального характеру і процедури службового розслідування. Здійснено аналіз їхніх стадій, проблем законодавчого врегулювання, особливостей дисциплінарноі відповідальності спеціального характеру. Зазначено наявність спірних моментів у процедурі проведення службового розслідування стосовно державних службовців та запропоновано шляхи їх вирішення. Проаналізовано дисциплінарні стягнення щодо публічних службовців, які містяться в різних нормативно-правових актах: у Кодексі законів про працю - догана та звільнення; Законі України «Про державну службу» - попередження про неповну службову відповідність $і$ затримка у присвоєнні до одного року чергового рангу або у призначенні на вищу посаду, які іменуються способами дисциплінарного впливу. Акцентується увага на тому, що Закон України «Про службу в органах місцевого самоврядування» не передбачає дисциплінарної відповідальності службовців органів місцевого самоврядування, що приводить до висновку про необхідність удосконалення відповідного законодавства. Проаналізовані дисциплінарні стягнення установлені Дисциплінарними статутами, які також містять різні види дисциплінарних стягнень за дисциплінарні порушення, і застосовуються до спеціальних категорій публічних службовців. На підставі аналізу чинного законодавства України розроблено конкретні пропозиціі щодо вдосконалення чинних законодавствчих актів, які регулюють порядок проходження адміністративних процедур державними службовцями та службовцями органів місцевого самоврядування на публічній службі. Ключові слова: адміністративні процедури, публічна служба, державна служба, служба в органах місцевого самоврядування, порядок проходження публічної служби, види адміністративних процедур.

The article carried out a comprehensive study of administrative procedures in the public service in Ukraine, considers the types of administrative procedures and the procedure for passing them. Attention is paid to the essence of public service, its structural elements, as well as to the concept of administrative procedure and its legal nature. The legal acts that govern the legal framework for administrative procedures are considered. Conclusions are drawn about the need to adopt a single regulatory act that would regulate the procedure for civil servants to go through with all its inherent procedures. A characteristic of the classification of administrative procedures that is characteristic of public service is provided. It analyzes the organizational procedures in the public service, which consist of the procedures for entering the service, the promotion procedures, the procedures for evaluating the performance of public servants, the incentive administrative procedures for public servants, and the jurisdictional administrative procedures in the public service, which consist of administrative procedures of a general and special nature and internal investigation procedures. The analysis of their stages, the problems of legislative regulation, the features of disciplinary responsibility of a special nature is carried out. The presence of controversial points in the procedure for conducting an internal investigation in relation to civil servants is indicated and ways to solve them are proposed. Disciplinary sanctions against public servants are analyzed, which are contained in various regulatory legal acts: in the Labor Code - reprimand and dismissal; The Law of Ukraine "On Public Service" - a warning of incomplete official compliance and detention in assignment of up to one year of the next rank or in appointment to a senior position, which are referred to as methods of disciplinary influence. The attention is focused on the fact that the Law of Ukraine "On Service in Local Government" does not provide for disciplinary liability of employees of local authorities, which leads to the conclusion that the relevant legislation must be improved. The disciplinary sanctions established by the Disciplinary Statutes and applied to special categories of public servants, which also contain various types of disciplinary sanctions for disciplinary violations, are analyzed. Based on the analysis of the current legislation of Ukraine, specific proposals have been developed regarding the improvement of the current legislation, which regulates the procedure for administrative procedures by public servants and employees of local self-government in the public service.

Key words: administrative procedures, public service, state service, service in local sels-governnet, order of proceeding of public service, kinds of administrative procedures. 
Постановка проблеми в загальному вигляді. Побудова демократичної правової держави Україна, здійснення адміністративної реформи, адаптація інституту публічної служби до стандартів Європейського Союзу потребують переосмислення цілої низки положень адміністративного права, систематизації й удосконалення адміністративного законодавства. Тому особливого значення набувають такі правові інститути адміністративного права, як адміністративний процес публічна служба, оскільки оптимальна організація й ефективність діяльності суб'єктів державного управління значною мірою зумовлені як порядком ïx функціонування (процедурами), так і дієвістю кадрової політики.

Запровадження адміністративного судочинства зумовило необхідність переосмислення такого правового явища, як адміністративний процес, визначення його структури і місця адміністративних процедур у ній, співвідношення понять «адміністративний процес», «адміністративні процедури», «адміністративні провадження» й «адміністративне судочинство». Крім теоретичного аспекту, великого значення набувають питання вдосконалення правового регулювання адміністративних процедур, механізму іх реалізації, класифікації, характеристики структури та визначення процесуального статусу учасників. Актуальність цих питань зумовлена, по-перше, недостатністю і неефективністю законодавчого регулювання адміністративних процедур; по-друге, відсутністю єдиного законодавчого акта 3 регулювання адміністративних процедур; по-третє, тим, що більшість адміністративних процедур регулюються нормами підзаконних нормативних актів відомчого характеру.

Аналіз останніх досліджень і публікацій. Теоретичною основою статті стали наукові праці таких учених, як: В.Б. Авер'янов, С.С. Алексєєв, Г.В. Атаманчук, А.П. Альохін, О.М. Бандурка, Д.М. Бахрах, Л.Р. БілаТіунова, Ю.П. Битяк, О.І. Бедний, В.М. Горшеньов, І.П. Голосніченко, Є.В. Додін, С.Д. Дубенко, М.І. Іншин, Д.П. Калаянов, Р.А. Калюжний, І.О. Картузова, С.В. Ківалов, Л.Є. Кисіль, Л.В. Коваль, Ю.М. Козлов, І.Б. Коліушко, В.К. Колпаков, Б.А. Кормич, В.Р. Кравець, Б.М. Лазарєв, Г.І. Леліков, О.Є. Луньов, В.Я. Малиновський, В.М. Манохін, О.Д.Оболенський, А.Ю. Осадчий, І.М. Пахомов, О.В. Петришин, Г.І. Петров, В.В. Прокопенко, Ю.М. Старілов, С.С. Студенікін, В.П. Тимощук, О.І. Харитонова, О.Ф.Фрицький, В.М.Шаповал, М.К.Якимчук та ін., теоретичні положення яких дозволили повно і всебічно охарактеризувати сутність процедур у публічній службі як окремого виду адміністративних процедур, а також законодавство в цій сфері діяльності. Водночас їхні напрацювання стосувалися окремих аспектів адміністративних процедур у публічній службі, що й зумовило здійснення цього дослідження.

Виділення не вирішених раніше частин загальної проблеми. Сьогодні у вітчизняній науковій літературі не існує єдиного погляду щодо стану і перспектив розвитку процесу професіоналізації в органах місцевого самоврядування. Загалом питання професіоналізації стосуються ефективності професійного навчання, діяльності працівників органів влади; є певні теоретичні доробки, що базуються на єдиному підході щодо кадрового забезпечення органів влади, професійного розвитку посадових осіб місцевого самоврядування. I водночас немає єдиного розуміння змісту цього поняття і єдиного правового механізму його забезпечення, що дало б змогу вирішити питання щодо політики професіоналізації з метою ліквідації проблем в адміністративно-процесуальному правовому регулюванні, розроблення, спрямування і визначення засобів удосконалення форм і методів професіоналізації служби в органах місцевого самоврядування.

Мета статті - визначення теоретико-правових засад адміністративних процедур упублічній службі, надання рекомендацій щодо вдосконалення чинного законодавства як про адміністративні процедури, так і про публічну службу.

Для досягнення мети в роботі передбачено вирішення таких завдань:

- установити й охарактеризувати процесуально-правовий аспект публічної служби України;

- визначити поняття й особливості адміністративних процедур у публічний службі;

- виокремити й охарактеризувати види адміністративних процедур у публічний службі;

- виокремити суб'єктний склад адміністративних процедур у публічній службі й охарактеризувати їх.

Виклад основного матеріалу. Поняття «публічна служба» $€$ узагальнюючим, воно має власну структуру і характеризується неоднозначністю наукових підходів до його розуміння - вузького і широкого. У контексті цього дослідження публічна служба розглядається у вузькому розумінні, як державна служба і як служба в органах місцевого самоврядування [6].

Публічна служба як багатоаспектне явище характеризується не тільки соціальним, політичним, правовим, організацій- 
ним, структурним і моральним змістом, але й процесуальним, якому в науці приділялося надто мало уваги, незважаючи на те, що він забезпечує функціонування публічної служби. Акцентовано увагу на тому, що процесуальний аспект нерозривно пов'язаний із такими аспектами, як правовий, організаційний, структурний, і зумовлений ними.

На підставі аналізу наукових доробок і чинного законодавства визначено адміністративні процедури як установлений нормами адміністративного права порядок діяльності органів державного управління з ухвалення нормативно-правових актів управління й вирішення індивідуальних адміністративних справ. Розгляд процедур у публічній службі як різновиду адміністративних процедур дав змогу визначити, що їм притаманні всі ознаки адміністративних процедур, але водночас вони мають свої особливсті: 1) реалізуються в рамках інституту державної служби та служби в органах місцевого самоврядування; б) відбуваються за участі обов'язкових суб'єктів - керівника (заступника керівника) органу, начальника структурного підрозділу, з одного боку, і публічного службовця - з іншого; в) характеризуються численністю і різноманітністю; г) між учасниками процедури існує внутрішньоорганізаційна підпорядкованість; ґ) організаційні адміністративні процедури відбуваються 3 певною циклічністю, тобто через визначені проміжки часу вони повторюються; д) регламентуються нормами адміністративного права [2].

Законодавство, яке регулює службові процедури, що містяться як в законах України, так і в підзаконних нормативно-правових актах, є розрізненим і не становить єдиної системи, що призводить до прогалин і колізій в їх здійсненні. Зазначено, що Закон України «Про державну службу» не містить чітко закріплених положень щодо проведення процедур конкурсу, атестації, щорічної оцінки діяльності державного службовця, заохочення державного службовця, притягнення його до дисциплінарної відповідальності, а Закон «Про службу в органах місцевого самоврядування» узагалі не містить положення про дисциплінарну відповідальність службовців органів місцевого самоврядування. У зв'язку із цим до низки законів запропоновано зміни щодо вдосконалення підстав і процедури дисциплінарної відповідальності публічного службовця [3].

Адміністративні процедури в публічній службі численні та різноманітні, стосуються всіх сторін проходження публічної служби і супроводжують всі сторони кар'єрного просування. У зв'язку із цим існує необхідність їх систематизації і класифікації, що має велике теоретичне, нормативне і практичне значення.

З урахуванням особливостей, стадійності, суб'єктного складу, процесуального статусу учасників і правових наслідків установлено, що адміністративні процедури в публічній службі варто класифікувати на: 1) організаційні адміністративні процедури; 2) юрисдикційні адміністративні процедури. Аналіз і характеристика зазначених видів процедур свідчать про те, що вони, у свою чергу, також є неоднорідними і мають свої особливості. Структуру організаційних адміністративних процедур становлять: а) процедури щодо вступу на публічну службу; б) процедури щодо оцінювання діяльності публічних службовців (атестація і щорічна оцінка); в) процедури щодо просування по публічній службі (кадровий резерв, стажування, присвоєння рангу, спеціального звання, чину); г) заохочувальні адміністративні процедури. Структуру юрисдикційних адміністративних процедур становлять: а) процедури щодо службового розслідування; б) процедури щодо притягнення до дисциплінарної відповідальності загального та спеціального характеру [4].

Порядок проведення процедури конкурсу на публічній службі недостатньо врегульований на законодавчому рівні. Закони України «Про державну службу», «Про службу в органах місцевого самоврядування», Порядок проведення конкурсу на заміщення вакантних посад державних службовців не закріплюють легального визначеного понять «конкурс» або «конкурсна процедура». «Конкурсна процедура» - це сукупність послідовно здійснюваних процедурних дій щодо оцінювання професійних, ділових і особистих якостей претендента на посаду публічного службовця, результатом яких є вирішення питання щодо виникнення чи не виникнення державно-службових відносин. Ця процедура найбільш поширена серед інших процедур вступу на публічну службу. Під час розгляду процедури конкурсу встановлено, що вона є складною, а її структура включає в себе стадії, які, у свою чергу, складаються з етапів, як-от: 1) підготовка та проведення конкурсу: а) публікація оголошення про проведення конкурсу; б) прийом документів від учасників конкурсу; в) попередній розгляд документів і допуск до участі в конкурсі; 2) проведення конкурсного іспиту та співбесіди: а) організаційна підготовка до іспиту; складання іспиту; б) підбиття підсумків іспиту; в) співбесіда; 3) ухвалення рішення за підсумками конкурсу; 4) оскарження ухваленого рішення; 5) виконання ухваленого рішення [1]. 
«Процедура призначення на посаду» являє собою сукупність послідовно здійснюваних процедурних дій щодо призначення особи на посаду I-II категорій службовців, яка здійснюється тільки щодо певної категорії осіб, визначених чинним законодавством, а саме: перших заступників і заступників міністрів, керівників, заступників керівників інших центральних органів виконавчої влади, урядових органів державного управління, керівників, заступників керівників державних підприємств та їх об'єднань у разі, коли ці особи, відповідно до законодавства, призначаються на посади та звільняються з посад Кабінетом Міністрів України, а також голів місцевих держадміністрацій. Виокремлено й охарактеризовано стадії та етапи процедури призначення: 1) порушення і підготовка справи щодо призначення: а) порушення справи про призначення; б) підготовка необхідних документів і матеріалів; в) проведення спеціальної перевірки відомостей, що подаються претендентами; г) проходження медичного огляду; 2) розгляд справи й ухвалення рішення; в) оскарження ухваленого рішення; д) виконання рішення [5].

Вагомою проблемою на сьогодні під час проведення процедур оцінювання діяльності публічних службовців $€$ їхня формальність у проведенні та неврегульованість на законодавчому рівні. Визначено причини, що зумовлюють недієвість щорічного оцінювання діяльності державних службовців, зокрема: а) відсутність єдиного організаційно-правового підходу до оцінювання діяльності державних службовців; б) недосконалість системи планування діяльності державних службовців як основної підстави для оцінювання успішності діяльності відповідно до визначених завдань; в) недосконалість механізму оцінювання; г) відсутність контролю за оцінюванням державних службовців; ґ) недооцінка керівниками та службовцями доцільності проведення оцінювання; д) недостатність інформаційного та методичного забезпечення оцінювання; є) відсутність реального впливу результатів оцінки діяльності державних службовців на просування по публічній службі [7].

Висновки. Визнано, що процесуальний аспект публічної служби визначає її як систему службових процедур, які $€$ рушійною силою організації та діяльності публічної служби. Він пов'язує публічну службу із процедурами, 3 яких вона складається та які регламентуються адміністративно-правовими нормами і забезпечують її функціонування. На публічній службі системою адміністративних процедур охоплюються фактично всі службові відношення з моменту їх виникнення до припинення.
Саме завдяки їм у конкретних діях відповідних суб'єктів реалізуються функції держави та місцевого самоврядування, вирішуються індивідуальні адміністративні справи (конкурс, призначення, атестація, присвоєння рангу, прийняття присяги, відставка тощо). Змістом проходження публічної служби є сукупність процедур щодо просування по публічній службі - від вступу на публічну службу до ї̈̈ припинення.

Встановлено, що належність процедур у публічній службі до адміністративних забезпечується таким: 1) складається з низки впорядкованих послідовних управлінських дій; 2) спрямована на досягнення певної мети (справи, оформлення, здійснення); 3) має послідовний характер і постійно перебуває в динаміці; 4) здійснюється у сфері державного управління.

Визначено, що адміністративні процедури в публічній службі - це регламентований нормами адміністративного права порядок розгляду і вирішення органами державного управління індивідуально-конкретної справи щодо публічного службовця, пов'язаної із проходженням ним публічної служби.

Адміністративні процедури в публічній службі, з огляду на їхні багатоаспектність і різноманітність, класифіковано на: 1) організаційні адміністративні процедури: а) процедури вступу на публічну службу, які, у свою чергу, включають процедури: конкурсу, зарахування на посаду, призначення на посаду, виборів на посаду, обрання на посаду; б) процедури оцінювання діяльності публічних службовців: процедури щорічної оцінки й атестаційної процедури; в) процедури щодо просування по публічній службі: процедури стажування, процедури кадрового резерву, процедури присвоєння рангу, чину, звання; г) заохочувальні адміністративні процедури; 2) юрисдикційні адміністративні процедури: а) процедури службового розслідування щодо публічних службовців; б) процедура притягнення до дисциплінарної відповідальності загального характеру; в) процедура притягнення до дисциплінарної відповідальності спеціального характеру.

Установлено, що більшість адміністративних процедур регламентовані підзаконними нормативними актами відомчого характеру, а частка законодавчих норм є незначною, що призводить до колізій і прогалин. 3 огляду на те, що під час здійснення окремих процедур ідеться про реалізацію конституційного права на публічну службу, зроблено висновок про необхідність пріоритетного регулювання адміністративних процедур у публічній службі законодавчими нормами. 
Запропоновано такі зміни і доповнення до чинного законодавства:

- закони України «Про державну службу» і «Про службу в органах місцевого самоврядування» доповнити розділом «Порядок вступу на державну службу», у якому врегулювати основні положення щодо: а) конкурсу; б) зарахування; в) призначення; г) обрання; ґ) затвердження;

- закони України «Про державну службу» і «Про службу в органах місцевого самоврядування» доповнити розділом «Оцінювання діяльності державних службовців», у якому закріпити основні положення атестації і щорічної оцінки;

- ч. 2 ст. 14 Закону України «Про державну службу» викласти в такій редакції: «До службовців можуть застосовуватися такі види дисциплінарних стягнень: а) догана; б) пониження в посаді або у спеціальному званні; в) попередження про неповну службову відповідність; г) звільнення з посади».

\section{ЛІТЕРАТУРА:}

1. Про державну службу : Закон України. URL: http://zakon1.rada.gov.ua/cgi-bin/laws/main.cgi? nreg=3723-12.
2. Про затвердження Положення про проведення атестації державних службовців : gостанова Кабінету Міністрів України від 28 грудуz 2000 р. № 1922. URL: http://zakon1.rada.gov.ua/cgi-bin/laws/ main.cgi?nreg=1922-2000-\%EF.

3. Алюшина Н. Оцінювання результативності та ефективності державно-управлінської діяльності: український та зарубіжний досвід. Вісник Національної академії державного управління при Президентові України. 2008. № 2. С. 104-117.

4. Боссарт Д., Деммке К. Державна служба у країнах-кандидатах до вступу до ЄС: нові тенденції та вплив інтеграційного процесу. Пер. 3 англ. О. Шаленко ; Нац. акад. держ. упр. при Президентові України. Кив : Міленіум, 2014. 128 с.

5. Василенко И. Административно-государственное управление в странах Запада: США, Великобритания, Франция, Германия : учебное пособие. Москва : Издат. корпорация «Логос», 2010. 200 c.

6. Державна служба: організаційно-правові основи і шляхи розвитку / за заг. ред. В. Авер'янова. Київ : Видавн. дім «Ін Юре», 2014. 273 с.

7. Дубенко С. Державна служба і державні службовці в Україні : навчально-методичний посібник. Київ : Ін Юре, 2010. 244 с.

8. Малиновський В. Державна служба: теорія і практика : навчальний посібник. Київ : Атіка, 2013. 160 c. 